\title{
Carotid dissection following a generalized tonic-clonic seizure
}

Figure Imaging findings in a patient with left internal carotid dissection
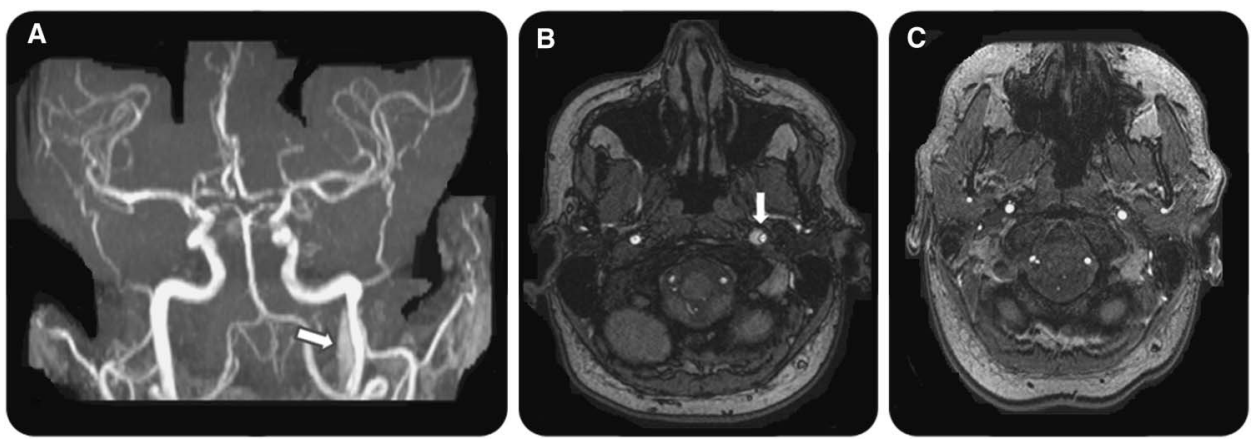

Magnetic resonance angiogram (A) and axial postcontrast (B) show dissection in left carotid artery (arrows). (C) Axial postcontrast 1 month later shows recanalization.

A 37-year-old woman experienced a generalized tonic-clonic seizure. Subsequent to the seizure, the patient observed left-sided face and neck pain. A left Horner syndrome was noted on examination. An MRI and magnetic resonance angiogram revealed a left skull base carotid artery dissection without infarction (figure, A and B). Previous MRI had shown normal carotid flow voids. The patient was treated conservatively and magnetic resonance angiogram 1 month later revealed recanalization (figure, C).

Carotid artery dissection has an incidence of 1.72 per $100,000 .^{1}$ Although carotid artery dissection is reported in association with minor trauma, there are no reports occurring in association with a seizure. ${ }^{2}$

Nicholas D. Child, MBChB, Gregory D. Cascino, $M D$

From the Mayo Clinic, Rochester, MN.

Author contributions: Nicholas D. Child and Gregory D. Cascino contributed to drafting and revising the manuscript. Dr. Cascino was responsible for the study concept.

Study funding. No targeted funding reported.

Disclosure: N. Child reports no disclosures. G. Cascino serves as an Associate Editor for Neurology ${ }^{\circledR}$. Go to Neurology.org for full disclosures.

Correspondence to Dr. Child: Child.Nicholas@mayo.edu

1. Lee VH, Brown RD, Mandrekar JN, Mokri B. Incidence and outcome of cervical artery dissection: a population-based study. Neurology 2006;67:1809-1812.

2. Debette S, Leys D. Cervical-artery dissections: predisposing factors, diagnosis, and outcome. Lancet Neurol 2009;8:668-678. 


\section{Neurology}

\section{Carotid dissection following a generalized tonic-clonic seizure \\ Nicholas D. Child and Gregory D. Cascino \\ Neurology 2013;80;1911 \\ DOI 10.1212/WNL.0b013e318292a356}

This information is current as of May 13, 2013

\section{Updated Information \& Services}

References

Citations

Subspecialty Collections

Permissions \& Licensing

Reprints including high resolution figures, can be found at: http://n.neurology.org/content/80/20/1911.full

This article cites 2 articles, 1 of which you can access for free at: http://n.neurology.org/content/80/20/1911.full\#ref-list-1

This article has been cited by 1 HighWire-hosted articles: http://n.neurology.org/content/80/20/1911.full\#\#otherarticles

This article, along with others on similar topics, appears in the following collection(s):

Carotid artery dissection

http://n.neurology.org/cgi/collection/carotid_artery_dissection

Complex partial seizures

http://n.neurology.org/cgi/collection/complex_partial_seizures

MRI

http://n.neurology.org/cgi/collection/mri

Information about reproducing this article in parts (figures,tables) or in its entirety can be found online at:

http://www.neurology.org/about/about_the_journal\#permissions

Information about ordering reprints can be found online:

http://n.neurology.org/subscribers/advertise

Neurology ${ }^{\circledR}$ is the official journal of the American Academy of Neurology. Published continuously since 1951, it is now a weekly with 48 issues per year. Copyright (O) 2013 American Academy of Neurology. All rights reserved. Print ISSN: 0028-3878. Online ISSN: 1526-632X.

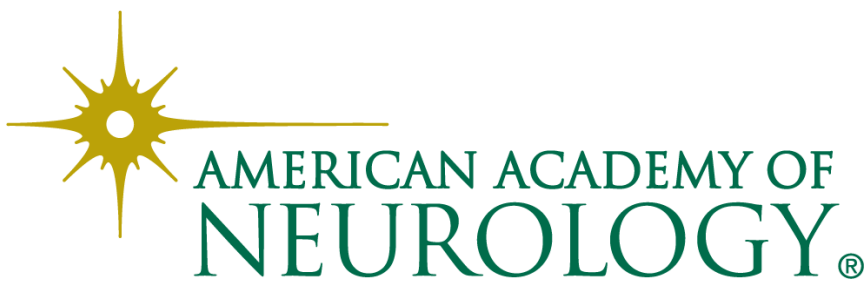

